\title{
Antibacterial activity of phytopathogenic Streptomyces strains against bacteria associated to clinical diseases*
}

\section{Atividade antimicrobiana de Streptomyces fitopatogênicas contra bactérias associadas a doenças de importância clínica}

\author{
Alex Augusto Tomaseto' ${ }^{1}$ (1) (orcid.org/0000-0002-8836-9165) \\ Marcel Costa Alpiste' (i) (orcid.org/0000-0001-7000-0864) \\ Alessandra Figueiredo de Castro Nassar ${ }^{2}$ (1) (orcid.org/0000-0002-9176-0974) \\ Suzete Aparecida Lanza Destéfano ${ }^{1 * *}$ (1) (orcid.org/0000-0002-7535-9224)
}

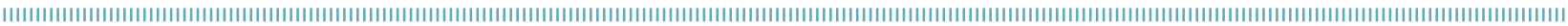

\begin{abstract}
The genus Streptomyces is associated with the ability to produce and excrete a variety of bioactive compounds, such as antibiotic, antifungal and antiviral. Biological active polyketide and peptide compounds with applications in medicine, agriculture and biochemical research are synthesized by PKS-I and NRPS genes. The evaluation of the presence of these genes associated with the biosynthesis of secondary metabolites in different phytopathogenic Streptomyces strains were performed using degenerated primers. The positive signal was observed in 58/63 Streptomyces strains for NRPS gene, 43/63 for PKS-I, and for PKS-II all the 63 strains showed positive signal of amplification. These strains also were tested with double layer agar-well technique against bacterial with clinical importance, and it was possible to observe the Streptomyces spp. strains were able to inhibit the growth of $14,20,13$ and 3 isolates Grampositive and Gram-negative bacteria, Staphylococcus aureus (ATCC 25923), Bacillus cereus (ATCC 14579), Pseudomonas aeruginosa (ATCC 27853) and Escherichia coli (ATCC 11775) respectively. The Streptomyces sp. strains IBSBF 2019 and IBSBF 2397 showed antibacterial activity against all four bacteriatarget tested.
\end{abstract}

KEYWORDS: biosynthetic pathway; antimicrobial activity; Streptomyces spp.
RESUMO: O gênero Streptomyces apresenta alta capacidade de produzir e excretar uma grande variedade de compostos biologicamente ativos, como antibióticos, antifúngicos e antivirais. Compostos biologicamente ativos de policetídeos e peptídeos com aplicaçóes na medicina, agricultura e pesquisas bioquímicas são sintetizados pelos genes PKS-I e NRPS. A avaliação da presença desses genes associados à biossíntese de metabólitos secundários em diferentes linhagens de Streptomyces fitopatogênicas foi realizada através do uso de primers degenerados. O sinal positivo foi observado em 58/63 linhagens de Streptomyces para o gene NRPS, 43/63 para o gene PKS-I e, para o gene PKS-II, todas as 63 linhagens apesentaram o sinal positivo de amplificaçáo. Essas linhagens também foram testadas através da técnica de dupla camada contra bactérias de importância clínica e foi possível observar que as linhagens de Streptomyces spp. foram capazes de inibir o crescimento de 14, 20, 13 e 3 isolados de bactérias Gram-positivas e Gram-negativas, Staphylococcus aureus (ATCC 25923), Bacillus cereus (ATCC 14579), Pseudomonas aeruginosa (ATCC 27853) e Escherichia coli (ATCC 11775), respectivamente. As linhagens de Streptomyces sp. ISBSF 2019 e 2397 apresentaram atividade antibacteriana contra todas as bactérias-alvo testadas.

PALAVRAS-CHAVE: vias biossintéticas; atividade antimicrobiana; Streptomyces spp.

\footnotetext{
'Laboratório de Bacteriologia Vegetal, Centro Avançado de Pesquisa em Proteção de Plantas e Saúde Animal, Instituto Biológico - Campinas (SP), Brazil ${ }^{2}$ Laboratório de Bacteriologia Geral, Centro de Pesquisa de Sanidade Animal, Instituto Biológico - São Paulo (SP), Brazil *This paper is part of the dissertation thesis of the first author.

**Corresponding author: suzete.destefano@sp.gov.br

Received on: 04/07/2020 Accepted on: 06/18/2020
} 


\section{INTRODUCTION}

Bacteria belonging to the Streptomyces genus comprise about 854 species within the actinomycete group (PARTE, 2018). They are gram-positive, have a filamentous structure, spores and plasmids with sizes ranging from 8 to $10 \mathrm{Mb}$, and most of them may have 20 gene cluster associated with the biosynthesis of secondary metabolites (LIN et al., 1993).

These microorganisms are known for the high ability to produce and excrete a variety of bioactive compounds which have a wide spectrum of activity, such as: antibacterial substances with antagonist potential (KANNAN et al., 2014), antifungal, antitumoral, antiparasitic, herbicide and antibiotic (MIYADOH, 1993; PADILHA, 1998; SALOMONI, 2009). Among these, it's possible to name: streptomycin (SELMAN; SCHATZ, 1994), cephalosporin (WILLIAMS, 1987), terramycin (FINLAY et al., 1950), and vancomycin (HIGGINS et al., 1958).

These substances have been extensively investigated from their biosynthetic pathways by amplifying genes like polyketide synthases (PKS) and non-ribosomal peptide synthetase (NRPS). These studies allowed a preliminary classification of Streptomyces strains based on their abilities to produce natural compounds belonging to aromatic group of polyketide, through the employment of primers targeted to this genus (METSÄ-KETELÄ et al., 1999).

Indiscriminate prolonged and use of synthetic chemicals antimicrobials has led to the selection of mutant and resistant pathogenic microorganisms such as Escherichia coli and Staphylococcus aureus. As a result, approximately 17 million people worldwide have died - mainly the elderly and children — due bacterial infections (PROCÓPIO et al., 2012). Therefore, the use of antibiotics of microbial origin has become an important efficient and economical alternative to this problem (VARGAS et al., 2004).

This study aimed to evaluate the presence of PKS and NRPS genes in different phytopathogenic Streptomyces strains and also verify their antimicrobial activity against bacteria associated to hospital infections and clinical diseases, such as Staphylococcus aureus, Bacillus cereus, Pseudomonas aeruginosa and E. coli.

\section{MATERIAL AND METHODS}

\section{Bacterial strains}

The 63 Streptomyces spp. strains used in this study were grown at $28^{\circ} \mathrm{C}$, in Yeast Malt Extract (YME - 0.4\% Bacto Yeast Extract; $1 \%$ Bacto Malt Extract; 0.4\% Glucose; 1.8\% Agar; $\mathrm{pH}$ 7.2) medium for seven days (SHIRLING; GOTTLIED, 1966). These bacteria were provided by Phytobacteria Culture Collection of Instituto Biológico (IBSBF), Campinas, São Paulo, Brazil.

The microorganisms of human clinical importance Staphylococcus aureus (ATCC 25923), Bacillus subtilis (ATCC 6051), Pseudomonas aeruginosa (ATCC 13388) - were incubated in BHI (Difco ${ }^{\circledR}$ ) culture, except E. coli (ATCC 11775) which was incubated in Levine $\left(\mathrm{Difco}^{\circledR}\right)$ selective culture at $37^{\circ} \mathrm{C}$ for $24 \mathrm{~h}$. The strains were provided by Dr. Alessandra Figueiredo de Castro Nassar from General Bacteriology Laboratory of the Animal Sanity Research Center, Instituto Biológico, São Paulo, Brazil.

\section{Type-I polyketide synthases, type- II polyketide synthases and non- ribosomal peptide synthetase genes of polymerase chain reaction amplification}

DNA extractions of Streptomyces spp. were performed according to PITCHER et al. (1989).

The amplification of the presence of the type-I polyketide synthases (PKS-I), type-II polyketide synthases (PKS-II) and NRPS genes of the Streptomyces strains was performed with degenerated primers described in the literature (Table 1) (AYUSO-SACIDO; GENILLOUD, 2005; METSÄ-KETELÄ et al., 1999).

Polymerase chain reaction (PCR) amplification tests were carried out in a thermocycler MyClycler (Bio-Rad), and amplified DNA fragments were separated on $1.5 \%$ agarose gels.

Table 1. Primers sequence of genes PKS-I, PKS-II and NRPS genes and PCR conditions.

\begin{tabular}{|c|c|c|c|c|c|c|c|c|}
\hline Gene & Primers & Sequence (5'- 3') & $\begin{array}{l}\text { Fragment } \\
\quad(\mathrm{bp})\end{array}$ & $\begin{array}{l}\text { primers } \\
(\mu \mathrm{M})\end{array}$ & $\begin{array}{l}\text { dNTPs } \\
(\mathrm{mM})\end{array}$ & $\begin{array}{l}\mathrm{MgCl}_{2} \\
(\mathrm{mM})\end{array}$ & $\begin{array}{c}\text { Taq } \\
\text { DNA } \\
\text { pol }\end{array}$ & Amplification program \\
\hline \multirow[b]{2}{*}{ PKS-I } & $\mathrm{K} 1$ & TSAAGTCSAACATCGGBCA & \multirow[b]{2}{*}{1100} & \multirow[b]{2}{*}{0.4} & \multirow[b]{2}{*}{0.2} & \multirow[b]{2}{*}{1.5} & \multirow[b]{2}{*}{2.0} & $95^{\circ} \mathrm{C} / 5 \mathrm{~min} ; 35 \mathrm{X}$ \\
\hline & M6R & CGCAGGTT SCSGTACCAGTA & & & & & & $\begin{array}{c}\left(95^{\circ} \mathrm{C} / 30 \mathrm{seg}, 58^{\circ} \mathrm{C} / 30 \mathrm{seg}\right. \\
\left.72^{\circ} \mathrm{C} / 4 \mathrm{~min}\right) ; 72^{\circ} \mathrm{C} / 10 \mathrm{~min}\end{array}$ \\
\hline \multirow[b]{2}{*}{ PKS-II } & IIPF6 & TSGC STGCTTCGAYGCSATC & \multirow[b]{2}{*}{$600-700$} & \multirow[b]{2}{*}{0.4} & \multirow[b]{2}{*}{0.2} & \multirow[b]{2}{*}{1.5} & \multirow[b]{2}{*}{2.0} & $95^{\circ} \mathrm{C} / 5 \mathrm{~min} ; 35 \mathrm{X}$ \\
\hline & IIPR6 & TGGAANCCGCCGAABCCGCT & & & & & & $\begin{array}{l}\left(95^{\circ} \mathrm{C} / 30 \mathrm{seg}, 58^{\circ} \mathrm{C} / 30 \mathrm{seg}\right. \\
\left.72^{\circ} \mathrm{C} / 4 \mathrm{~min}\right) ; 72^{\circ} \mathrm{C} / 10 \mathrm{~min}\end{array}$ \\
\hline \multirow[b]{2}{*}{ NRPS } & A3 & GCSTACSYSATSTACACSTCSGG & \multirow[b]{2}{*}{700} & \multirow[b]{2}{*}{0.4} & \multirow[b]{2}{*}{0.2} & \multirow[b]{2}{*}{1.5} & \multirow[b]{2}{*}{2.0} & $95^{\circ} \mathrm{C} / 5 \mathrm{~min} ; 35 \mathrm{X}$ \\
\hline & A7R & SASGTCVCCSGTSCGGT AS & & & & & & $\begin{array}{c}\left(95^{\circ} \mathrm{C} / 30 \mathrm{seg}, 58^{\circ} \mathrm{C} / 30 \mathrm{seg},\right. \\
\left.72^{\circ} \mathrm{C} / 4 \mathrm{~min}\right) ; 72^{\circ} \mathrm{C} / 10 \mathrm{~min}\end{array}$ \\
\hline
\end{tabular}

Bp: base pairs; ambiguous bases: B - (C/G/T); S - (C/G); N - (G/A/C/T); Y - (C/T) and V - (A/C/G). AYUSO-SACIDO; GENILLOUD (2O05). 


\section{Antibacterial activity testing using spot inoculation method (double layer agar-well technique)}

This assay plate consists of double layers. On the lower basal layer, Streptomyces spp. strains were inoculated with platinum needle, pricked on Petri dishes $(90 \times 15 \mathrm{~mm})$ containing YME culture. The inoculation layout were three strains per plate. These were allowed to colonize in order to produce active metabolites at $28^{\circ} \mathrm{C}$ for 14 days. After that period, it was inoculated on $9 \mathrm{~mL}$ of MuellerHinton agar (MUELLER; HILTON, 1941) a solution of $1 \mathrm{~mL}$ of distilled water with a bacteria-targeted suspension that contained $10^{8}$ colony forming units (CFU) per $\mathrm{mL}$ (according to the 0.5 dilution on the Mac Farland scale) that was spilled on the colonized plates. These were then incubated for $24 \mathrm{~h}$ at $28^{\circ} \mathrm{C}$. The presence of the antibacterial compounds was observed through transparent zones around the colonies of Streptomyces spp., indicating the absence of bacterial growth. The assays were performed in five replicates.

\section{RESULTS}

The Table 2 shows the positive signal for amplification with specific pair of primers used for each expected biosynthetic gene. All 65 strains analyzed herein showed positive results for at least one biosynthetic gene.

All Streptomyces spp. strains (63) tested showed positive signal for PKS-II gene, otherwise the presence of PKS-I and NRPS genes were variable, 43/63 for PKS-I and 58/63 NRPS genes, respectively. In the antimicrobial activity assays, 14 Streptomyces strains were able to inhibit the growth of Staphylococcus aureus (ATCC 25923), 20 against Bacillus cereus (ATCC 14579), 13 for Pseudomonas aeruginosa (ATCC 27853) and 3 for E. coli (ATCC 11775). The IBSBF 2019 and IBSBF 2397 strains presented antimicrobial activity against all four indicator bacteria.

\section{DISCUSSION}

PKS-I and NRPS biosynthetic systems have been extensively described not only in actinomycetes but also in myxobacteria, cyanobacteria and other bacterial and filamentous fungi. The biosynthetic potential of different actinomycete taxonomic groups with the presence of NRPS and PKS-I was investigated by AYUSO-SACIDO; GENILLOUD (2005) in a collection of 210 reference strains representative of 33 different genera. The authors found NRPS sequences in $79.5 \%$ of these strains, and PKS-I were detected only in 56.7\%. In 35 Streptomyces strains, they observed $97 \%$ (32 strains) and 79\% (26 strains) of presence of NRPS and PKS-I, respectively. Similar results with actinomycetes were found by JANSO; CARTER (2010) with 100 and $66 \%$ as well. In our study, we found 59 strains (91\%) with positive signal for NRPS gene, which is related to the production of important antibiotics, such as penicillins, vancomycins and cyclosporins, and $70 \%$ for PKS-I gene. This non-ribosomal pathway is involved in the production of complex compounds that have antibiotic activity, as rapamycin, rifamycin, nystatin and erythromycin (BARRETO, 2013), antitumor, antiparasitics and immunosuppressants (MELO, 2009).

Previous studies carried out by JANSO; CARTER (2010) indicated positive signal for $79 \%$ of the strains tested with the pair of primers that amplify the PKS-II gene which is responsible for the formation of aromatic phenolic compounds (BARRETO, 2013), but in our study $100 \%$ of Streptomyces strains showed positive amplification for this gene.

Some of the pathways encoding these genes may not be functional because the strains possess the genetic capacity to produce some secondary metabolites if cultivated under proper conditions (JANSO; CARTER, 2010). In our study, 24 strains showed positive signal for PKSs and NRPS genes, but do not showed antimicrobial activity.

A broad range of biologically active polyketide and peptide compounds with applications in medicine, agriculture and biochemical research are synthesized by PKS-I and NRPS (AYUSOSACIDO; GENILLOUD, 2005). The Streptomyces genus has been the focus of intensive research since this group of bacteria apparently has ability to produce a large variety of different bioactive compounds. From 1950s to 1970s, numerous new bioactive molecules were discovered, and used into various clinical uses (METSÄ-KETELÄ et al., 1999; WANG et al., 2015).

Herein, the strains were tested against bacteria with clinical importance and it was possible to observe that $31 \%$ (20 strains) were able to inhibit the growth of Bacillus cereus strain (ATCC 14579) and 21\% (14 strains) of Staphylococcus aureus (ATCC 25923). Among the samples that showed antimicrobial activity, eight Streptomyces strains were able to inhibit the growth of two Gram-positive bacteria. This result confirms the observations made by previous researches, such as DUARTE et al. (2009), who study Streptomyces samples that showed inhibition halo against bacteria of clinical importance. Likewise, other different studies made by other authors (SALOMONI, 2009; ANTUNES, 2013) obtained approximately $80 \%$ of the samples of actinomycetes showing inhibition halo against strains like Staphylococcus aureus and Bacillus sp.

The Gram-positive bacteria have different resistance mechanisms, por example, antibiotic destruction (enzymes that catalyze antibiotic degradation or that modify functional groups of pharmacological importance, creating inactive functions for cell recognition); continuous antibiotic efflux (mutant genes overexpress membrane carrier proteins, causing the exit of the antibiotic into the extracellular medium faster than its diffusion through the bacterial membrane); the reprogramming and the modification of targeted structure (macromolecules that are targets for the antibiotic, such as ribosomes, proteins, etc.). The mechanisms are structurally modified from genes that express them, affecting recognition of the drug. These bacteria 
Table 2. Screening of NRPS and PKS genes presence and evaluation of antimicrobial activity of Streptomyces spp. strains against clinical importance bacteria.

\begin{tabular}{|c|c|c|c|c|c|c|c|c|}
\hline \multirow[b]{2}{*}{ Genus/Species } & \multicolumn{4}{|c|}{ Genes } & \multicolumn{4}{|c|}{ Clinical importance bacteria } \\
\hline & IBSBF & NRPS & PKS-I & PKS-II & $\begin{array}{l}\text { S. aureus } \\
\text { (ATCC } \\
\text { 25923) }\end{array}$ & $\begin{array}{l}\text { B. cereus } \\
\text { (ATCC } \\
6051 \text { ) }\end{array}$ & $\begin{array}{c}\text { P. aeruginosa } \\
\text { (ATCC } \\
\text { 133388) }\end{array}$ & $\begin{array}{c}\text { E. coli } \\
\text { (ATCC 11775) }\end{array}$ \\
\hline \multirow{28}{*}{ S. scabiei } & 1884 & - & + & + & - & - & - & - \\
\hline & 1886 & + & + & + & - & + & + & - \\
\hline & 1936 & + & - & + & - & - & - & - \\
\hline & 2005 & + & - & + & + & + & - & - \\
\hline & 2006 & + & + & + & + & + & + & - \\
\hline & 2124 & - & - & + & - & + & - & - \\
\hline & 2147 & + & + & + & - & - & - & - \\
\hline & 2203 & + & - & + & - & - & - & - \\
\hline & 2204 & + & + & + & - & - & - & - \\
\hline & 2228 & + & - & + & - & + & - & - \\
\hline & 2243 & + & + & + & - & - & - & - \\
\hline & 2248 & + & + & + & - & - & - & - \\
\hline & 2250 & + & - & + & - & + & + & - \\
\hline & 2257 & + & - & + & - & - & - & - \\
\hline & 2282 & - & - & + & - & + & - & - \\
\hline & 2292 & + & - & + & - & + & - & - \\
\hline & 2298 & + & + & + & - & - & - & - \\
\hline & 2315 & + & + & + & - & + & + & - \\
\hline & 2316 & + & + & + & - & - & - & - \\
\hline & 2317 & + & + & + & - & - & - & - \\
\hline & 2359 & + & + & + & - & - & - & - \\
\hline & 2388 & + & + & + & - & - & - & - \\
\hline & 2403 & + & + & + & - & - & - & - \\
\hline & 2475 & + & + & + & - & - & - & - \\
\hline & 2500 & + & + & + & + & + & - & - \\
\hline & 2501 & + & + & + & - & - & - & - \\
\hline & 2502 & + & + & + & - & - & - & - \\
\hline & 2523 & - & + & + & - & + & - & - \\
\hline \multirow{10}{*}{ S. europaeiscabiei } & 1943 & + & - & + & - & - & - & - \\
\hline & 1944 & + & + & + & - & - & - & - \\
\hline & 2162 & + & + & + & - & - & - & - \\
\hline & 2472 & + & + & + & - & - & - & - \\
\hline & 2473 & + & + & + & - & - & - & - \\
\hline & 2474 & + & + & + & + & - & - & - \\
\hline & 2498 & + & + & + & - & + & - & - \\
\hline & 2499 & + & + & + & - & - & - & - \\
\hline & 2508 & + & + & + & - & - & - & - \\
\hline & 2510 & - & + & + & - & - & + & - \\
\hline \multirow{5}{*}{ S. caviscabies } & 2021 & + & + & + & + & - & - & - \\
\hline & 2236 & + & + & + & + & - & - & - \\
\hline & 2260 & + & + & + & + & - & - & - \\
\hline & 2368 & + & + & + & + & - & - & - \\
\hline & 2392 & + & + & + & - & - & - & - \\
\hline S. sampsonii & 2360 & + & + & + & - & - & - & - \\
\hline \multirow{19}{*}{ Streptomyces sp. } & 2019 & + & - & + & + & + & + & + \\
\hline & 2397 & + & - & + & + & + & + & + \\
\hline & 2402 & + & + & + & + & + & - & - \\
\hline & 2430 & + & + & + & - & + & + & - \\
\hline & 2431 & + & - & + & + & + & - & - \\
\hline & 2439 & + & - & + & - & + & - & - \\
\hline & 2449 & + & - & + & - & + & + & - \\
\hline & 2486 & + & - & + & - & - & - & - \\
\hline & 2528 & - & + & + & - & - & - & - \\
\hline & 2247 & + & - & + & + & + & + & - \\
\hline & 2352 & + & - & + & - & - & + & + \\
\hline & 2390 & + & + & + & - & + & - & - \\
\hline & 2395 & + & + & + & - & - & - & - \\
\hline & 2509 & + & + & + & - & - & - & - \\
\hline & 2520 & + & + & + & - & - & + & - \\
\hline & 2503 & + & + & + & - & - & - & - \\
\hline & 2507 & + & - & + & - & - & + & - \\
\hline & 2229 & + & + & + & - & - & - & - \\
\hline & 2343 & + & - & + & - & - & - & - \\
\hline
\end{tabular}

$(+)$ positive amplification signal for determinate gene; (-) negative amplification signal. 
may use only one or a number of these mechanisms, overcoming the more recent antibiotics and making even more important new researches for new antibiotics (SILVEIRA et al., 2006; ALEKSHUN; LEVY, 2007; MULVEY; SIMOR, 2009).

In our study, three Streptomyces spp. strains that were evaluated against Gram-negative bacteria showed an inhibition halo for E. coli, similar result obtained by DUARTE et al. (2009). Previous research carried out by CARVALHO (2014) showed antimicrobial activity of bacteria of the genus Streptomyces against strains of multi-resistant (20/24 strains) of E. coli and Pseudomonas aeruginosa.

Our study revealed that 13 phytopathogenic Streptomyces spp. strains tested against Pseudomonas aeruginosa (ATCC 13388) were able to inhibit its growth, becoming our results promising when it comes to clinical importance bacteria, mainly Gram-negative bacteria such as E. coli and $P$. aeruginosa which are responsable by hospital infections in the last century, perphaps due to the antibiotic resistance and the ability to forms complex biofilms (STOVER et al., 2000).

The high mutation rate of these Gram-negative strains and their capacity to form complex biofilms on surfaces and even in water reservoirs represent high health risks in hospitals (LIVERMORE, 2002; SAUER et al., 2002; VILLAS BÔAS; RUIZ, 2004). Previous studies showed that approximately $35 \%$ of hospital infection cases in erderly are associated with $P$. aeruginosa strains (VILLAS BÔAS; RUIZ, 2004). Still, most of the cases of hospitals infections in the world are caused by Gram-negative bacteria and 14\% of them are caused by this bacterial species (NOGUEIRA et al., 2009).

Many studies of evaluation of antimicrobial potential against bacteria of clinical importance have shown that Gram-negative strains often exibhit high resistance against antimicrobial activity assays. There is no data explaining the reason behind this, however it's known that, despite having a less rigid cell wall structure than Gram-positive ones, these bacteria have a more chemically complex cell wall; for example, among the constituents of the wall, it is the lipopolysaccharide, which determines the antigenicity, toxicity and pathogenicity of these microorganisms. This group also has a higher lipid content and these characteristics may be involved in the resistance against antimicrobial activity assays (VARGAS et al., 2004).

There is a lot of evidence that antimicrobial resistance is already present in natural environments and that it spreads naturally through horizontal gene transfer (HGT) (FUENTEFRIA et al., 2008). Besides intragenomic recombination, the HGT events in Stretomyces increase the recombinant effect, justifying the high variation of polyketide compounds over thousand of years of evolution. According to FISCHBACH et al. (2008), the collective gene evolution also explains the diversification and the propagation of PKs among various groups of microorganisms. A key factor in the propagation of these poliketide pathways is the fact that these molecules will often grant adaptive advantages to their host often propagated by plasmids.

\section{CONCLUSION}

There is a constant necessity to discover new bioactive compounds with antibiotic properties and ability to inhibit the growth of pathogenic microorganimsm. The phytophatogenic Streptomyces strains tested in this study showed promising results for the production of biosynthetic compounds with antimicrobial activity. The extraction, characterization and purification of these active molecules may result in new bioactive compounds with clinical importance.

ACKNOWLEDGEMENTS: We express our gratitude to teachers and students who in some way or another contributed to the consolidation of this project.

FUNDING: This study was financed in part by the Coordenação de Aperfeiçoamento de Pessoal de Nível Superior - Brasil (CAPES) - Finance Code 001 and by the Conselho Nacional de Desenvolvimento Científico e Tecnológico (CNPq) (research fellowship to S.A.L. Destefano - CNPq PQ 30.31.22/2017-0)

CONFLICTS OF INTEREST: The authors certify that they have no commercial or associative interest that represents a conflict of interest in connection with the manuscript.

ETHICAL APPROVAL: Not applicable.

AVAILABILITY OF DATA AND MATERIAL: The datasets generated and/or analyzed during the current study are available in http://www.biologico.agricultura.sp.gov.br/pos/uploads/files/pdf/2016/Alex.pdf.

AUTHORS' CONTRIBUTIONS: Conceptualization: Tomaseto, A.A.; Destefano, S.A.L. Data curation: Tomaseto, A.A.; Alpiste, M.C. Formal analysis: Tomaseto, A.A.; Destefano, S.A.L. Funding acquisition: Destefano, S.A.L. Investigation: Tomaseto, A.A., Alpiste, M.C. Methodology: Tomaseto, A.A.; Alpiste, M.C.; Nassar, A.F.C. Project administration: Tomaseto, A.A., Destefano, S.A.L. Resources: Tomaseto, A.A.; Nassar, A.F.C.; Destefano, S.A.L. Supervision: Nassar, A.F.C.; Destefano, S.A.L. Validation: Nassar, A.F.C.; Destefano, S.A.L. Visualization: Tomaseto, A.A.; Destefano, S.A.L. Writing original draft: Tomaseto, A.A. Writing — review \& editing: Destefano, S.A.L. 


\section{REFERENCES}

ALEKSHUN, N.M.; LEVY, S.B. Molecular mechanisms of antibacterial multidrug resistance. Cell, v.128, n.6, p.1037-1050, 2007. https://doi.org/10.1016/j.cell.2007.03.004

ANTUNES, T.C. Avaliação de moléculas bioativas produzidas por isolados actinomicetos contra cocos gram positivos de origem clínica. 2013. 97f. Dissertation (Master in Environmental Microbiology) - Universidade Federal do Rio Grande do Sul, Porto Alegre, 2013.

AYUSO-SACIDO, A.; GENILLOUD, O. New PCR primers for the screening of NRPS and PKS-I systems in actinomycetes: Detection and distribution of these biosynthetic gene sequences in major taxonomic groups. Microbial Ecology, v.49, n. 1, p. 10-24, 2005. https://doi.org/10.1007/s00248-004-0249-6

BARRETO, E.N. Potencial antimicrobiano de actinobactérias e detecção dos genes associados às vias de NRPS e PKS-I. 2013.48f. Dissertation (Master in Industrial Biotechnology) - Universidade Tiradentes, Aracajú, 2013.

CARVALHO, T.S. Avaliação da atividade antibacteriana do actinomiceto endofítico R $18(6)$ contra bactérias gram-negativas multirresistentes. 2014. 90f. Dissertation (Master in Environmental Microbiology) - Universidade Federal do Rio Grande do Sul, Porto Alegre, 2014.

DUARTE, M.W.; DAMASCENO, R.G.; SALAMONI, S.P.; OLIVEIRA, M.F.; SAND, S.T.V.D. Atividade antimicrobiana e produção de enzimas extracelulares por actinomicetos isolados de solo. 2009. 33f. Undergraduate thesis (Biological Sciences) - Universidade Federal do Rio Grande do Sul, Porto Alegre, 2009.

EUZÉBY, J.P. List of bacterial names with standing in nomenclature: a folder available on the Internet. International Journal of Systematic Bacteriology, v.47, p.590-592, 1997. https://doi. org/10.1099/00207713-47-2-590

FINLAY, A.C.; HOBBY, G.L.; P'AN, S.Y.; REGNA, P.P.; ROUTIEN, J.B.; SEELEY, D.B.; SHULL, G.M.; SOBIN, B.A.; SOLOMONS, I.A.; VINSON, J.W.; KANE, J.H. Terramycin, a new antibiotic. Science, v. 11 1, n.2874, p.85, 1950. https://doi.org/10.1126/ science. 111.2874 .85

FISCHBACH, M.A.; WALSH, C.T.; CLARDY, J. The evolution of gene collectives: How natural selection drives chemical innovation. Proceedings of the National Academy of Sciences, v. 105, p.46014608, 2008. https://doi.org/10.1073/pnas.0709132105

FUENTEFRIA, D.B.; FERREIRA, A.E.; GRÄF, T.; CORÇÃO, G. Pseudomonas aeruginosa: disseminação de resistência antimicrobiana em efluente hospitalar e água superficial. Revista da Sociedade Brasileira de Medicina Tropical, v.41, n.5, p.470-473, 2008. http://dx.doi.org/10.1590/ s0037-86822008000500007

HIGGINS, H.M.; HARRISON, W.H.; WILD, G.M.; BUNGAY, H.R.; MCCORMICK, M.H. Vancomycin, a new antibiotic. VI. Purification and properties of vancomycin. Antibiotics Annual, v.5, p.906914, 1957-1958.
JANSO, J.E.; CARTER, G.T. Biosynthetic potential of phylogenetically unique endophytic actinomycetes from tropical plants. Applied and Environmental Microbiology, v.76, n.13, p.4377-4386, 2010. https://doi.org/10.1128/AEM.02959-09

KANNAN, R.R.; INIYAN, A.M.; VICENT, S.G.P. Production of a compound against methicillin resistant Staphylococcus aureus (MRSA) from Streptomyces rubrolavendulae ICN3 \& its evaluation in zebrafish embryos. Indian Journal of Medical Research, v. 139 , n.6, p.913-920, 2014.

LIN, Y.S.; KIESER, H.M.; HOPWOOD, D.A.; CHEN, C.W. The chromosomal DNA of Streptomyces lividans 66 is linear. Molecular Microbiology, v.10, n.5, p.1 103, 1993. https://doi. org/10.1111/j.1365-2958.1994.tb01342.x

LIVERMORE, D.M. Multiple mechanisms of antimicrobial resistance in Pseudomonas aeruginosa: our worst nightmare? Clinical Infectious Diseases, v.34, n.5, p.634-40, 2002. https://doi. org/10.1086/338782

MELO, F.M.P. Bioprospecção de Actinobactérias rizoféricas de milho (Zea mays L.) com atividade antifúngica. 2009. 105f. Thesis (Doctorate in Biotechnology) - Universidade de São Paulo, São Paulo, 2009.

METSÄ-KETELÄ, M.; SALO, V.; HAL, L.; HAUTALA, A.; HAKALA, J.; MÄNTSÄLÄ, P.; YLIHONKO, K. An efficient approach for screening minimal PKS genes from Streptomyces. FEMS Microbiology Letters, v.180, n.1, p.1-6, 1999. https://doi. org/10.1111/j.1574-6968.1999.tb08770.x

MIYADOH, S. Research on antibiotic screening in Japan over the last decade: A producing microorganism approach. Actinomycetologica, v.7, n.2, p.100-106, 1993. https://doi. org/10.3209/saj.7_100

MUELLER, J.H.; HINTON, J. A Protein-Free Medium for Primary Isolation of the Gonococcus and Meningococcus. Proceedings of the Society for Experimental Biology and Medicine, v.48, n. 1, p.330333, 1941. https://doi.org/10.3181/00379727-48-13311

MULVEY, M.R.; SIMOR, A.E. Antimicrobial resistance in hospitals: How concerned should we be? Canadian Medical Association Journal, v.180, n.4, p.408-415, 2009. https://doi.org/10.1503/ cmaj.080239

NOGUEIRA, P.S.F.; MOURA, E.R.F.; COSTA, M.M.F.; MONTEIRO, W.M.S.; BRONDI, L. Perfil da infecção hospitalar em um hospital universitário. Revista de Enfermagem da UERJ, v.17, n.1, p.96$101,2009$.

PADILHA, G. Biologia molecular de Streptomyces e aplicações industriais. In: MELO, I.S.; AZEVEDO, J.L. Ecologia microbiana. Jaguariúna: Embrapa CNPMA, 1998. p.327-343.

PARTE, A.C. LPSN - List of Prokaryotic names with Standing in Nomenclature (bacterio.net), 20 years on. International Journal of Systematic and Evolutionary Microbiology, v.68, n.6, 18251829, 2018. https://doi.org/10.1099/ijsem.0.002786 
PITCHER, D.G.; SAUNDERS, N.A.; OWEN, R.J. Rapid extraction of bacterial genomic DNA with guanidium thiocyanate. Letters Applied of Microbiology, v.8, n.4, p.151-156, 1989. https://doi. org/10.1111/j.1472-765X.1989.tb00262.x

PROCÓPIO, R.E.L.; SILVA, I.R.; MARTINS, M.K.; AZEVEDO, J.L.; ARAÚJO, J.M.; Antibiotics produced by Streptomyces. The Brazilian Journal of Infectious Diseases, v.16, n.5, p.466-471, 2012 . https://doi.org/10.1016/j. bjid.2012.08.014

SALOMONI, S.P. Avaliação da atividade microbiana de isolados de Streptomyces e estudo da produção de moléculas bioativas. 2009. 151f. Thesis (Doctorate in Agricultural and Environmental Microbiology) - Universidade Federal do Rio Grande do Sul, Porto Alegre, 2009.

SAUER, K.; CAMPER, A.K.; EHRILICH, G.D.; COSTERTON, J.W.; DAVIES, D.G. Pseudomonas aeruginosa Displays multiple phenotypes during development as a biofilm. Journal of Bacteriology, v.184, n.4, p.1140-1154, 2002. https://doi.org/10.1128/ jb. 184.4.1140-1 154.2002

SELMAN, A.W.; SCHATZ, A. Streptomycin - origin, nature, and properties. Journal of the American Pharmaceutical Association, v.34, n.11, p.273-291, 1944. https://doi.org/10.1002/ jps.3030341102

SHIRLING, E.B.; GOTTLIEB, D. Methods for characterization of Streptomyces species. International Journal of Systematic and Evolutionary Microbiology, v.16, n.3, p.313-340, 1966. https:// doi.org/10.1099/00207713-16-3-313
SILVEIRA G.P.; NOME, F.; GESSER, J.C.; SÁ, M.M.; TERENZI, H. Estratégias utilizadas no combate à resistência bacteriana. Química Nova, v.29, n.4, p.844-855, 2006. http://dx.doi.org/10.1590/ S0 $100-40422006000400037$

STOVER, C.K.; PHAM, X.Q.; ERWIN, A.L;; MIZOGUCHI, S.D.; WARRENER, P.; HICKEY, M.J.; BRINKMAN, F.S.; HUFNAGLE, W.O.; KOWALIK, D.J.; LAGROU, M.; GARBER, R.L.; GOLTRY, L.; TOLENTINO, E.; WESTBROCKWADMAN, S.; YUAN, Y.; BRODY, L.L.; COULTER, S.N.; FOLGER, K.R.; KAS, A.; LARBIG, K.; LIM, R.; SMITH, K.; SPENCER, D.; WONG, G.K.; WU, Z.; PAULSEN, I.T.; REIZER, J.; SAIER, M.H.; HANCOCK, R.E.; LORY, S.; OLSON, M.V. Complete genome sequence of Pseudomonas aeruginosa PAO1, an opportunistic pathogen. Nature, v.406, n.6799, p.959964, 2000. https://doi.org/10.1038/35023079

VARGAS, A.C.; LOGUERCIO, A.P.; WITT, N.M.; COSTA, M.M.; SILVA, M.S.; VIANA, L.R. Atividade antimicrobiana "in vitro" de extrato alcoólico de própolis. Ciência Rural, v.34, n.1, p.159-163. 2004. https://doi.org/10.1590/SO103-84782004000100024

VILLAS BÔAS, P.J.F.; RUIZ, T. Ocorrência de infecção hospitalar em idosos internados em hospital universitário. Revista de Saúde Pública, v.38, v.3, p.372-378. 2004. https://doi.org/10.1590/ S0034-89102004000300006

WANG,H.; SIVONEN, K.; FEWER, D.P.Genomic insights into the distribution, genetic diversity and evolution of polyketide synthases and nonribosomal peptide synthetases. Current Opinion in Genetics \& Development, v.35, p.39-85, 2015. https://doi.org/10.1016/j.gde.2015.10.004

WILLIAMS, J.D. The cephalosporin antibiotics. n.1.v.14. Auckland, New Zealand: Adies Press, 1987. 